\title{
How Zakat can affect Inflation in Indonesia through Modified Keynesian Consumption
}

\author{
Angga Erlando ${ }^{1}$ and An'im Kafabih ${ }^{2}$ \\ ${ }^{1}$ Faculty of Economics and Business, Airlangga University, Indonesia \\ ${ }^{2}$ Faculty of Economics and Business, Brawijaya University, Indonesia
}

\section{Abstract}

As bank of Indonesia with its inflation targeting failed, mainy, to maintain inflation in the range that has been decided and also Indonesia never gain near zero inflation yet as a form of price stability based on some economists, the main objective of this paper is to investigate on how to control level of inflation through modified keynesian consumption model that mainly incorporates zakat and israf. The data that are gathered from 2002-2016 (15 observation years) because of the very lack of data, however, these data shows BLUE and no spurious regression. Venn diagram is utilised to compute important variables in the model, simple regresion and some diagnostic test

Corresponding Author: Angga Erlando

erlandolpdp@gmail.com

Received: 10 February 2019

Accepted: 14 March 2019

Published: 28 March 2019

Publishing services provided by Knowledge E

(c) Angga Erlando and An'im

Kafabih. This article is distributed under the terms of the

Commons Attribution License, which permits unrestricted use and redistribution provided that the original author and source are credited.

Selection and Peer-review under the responsibility of the ICIEBP Conference Committee. are conducted to study the coefficient econometrically, and unit root test is conducted to see whether any spurious regression or not. the result shows that zakat will make MPC of muzakki lower than mustahik, as muzakki pays higher zakat to mustahik, this condition will not be followed by increasing level of inflation. However, the study also shows that existing israf (extravagant in consumption) will gradually reduce the ability of zakat to stabilise inflation.

Keywords: Consumption; Keynesian; Zakat; Muzakki, Mustahik, Israf; Inflation

\section{Introduction}

Start from 1999, Bank of Indonesia (BI) has been adopting inflation targeting to stabilise price by influencing expectation of inflation and coordinating with government (Kenward, 2013; Bank Indonesia Annual Report, 2016). However, based on data publised on official Bl's website from 2001 to 2016, BI has failed to achieve inflation in target range 11 times.

Oliver Blanchard explained that stable price is zero inflation. Kunio Okina, ex-director at the bank of Japan, also argued that zero level of inflation is an optimal target for monetary policy (Nishizaki, K. And Watanabe, 2000). However, based on bank Indonesia monthly data, Indonesia never achieve zero inflation or event near zero inflation yet. The lowest inflation ever gained is $2.41 \%$ in November 2009, and there is no level of inflation at the rate of $2 \%$ or even $1 \%$. 
In Indonesia, Penn World table 9 (2018) reported that level of consumption is higher compared to investment and government expenditure. As in standart macroeconomics model explains that general price is determined by GDP that consist of consumption, investment and government expenditure, it can be said that level of inflation in Indonesia is caused by the high level of consumption. Therefore, this research try to investigate how to control level of inflation through modified keynesian consumption model introduced and revised by lqbal (1985) and Hasan (1990;2005).

\section{Theoretical Foundation}

\subsection{Modified Keynesian consumption model}

Based on Keynesian consumption model, consumption is determined by level of disposable income of the ones, and the disposable income will be affected by taxation. Keynesian consumption model is denoted as $\mathrm{C}=\mathrm{a}+\mathrm{bYd}$ where $\mathrm{C}$ stands for consumption, Yd is disposable income (income after the payment of all taxes, (Mankiw, 2012)), 'a' is consumption condition when disposable income is zero, and ' $b$ ' is Marginal Propensity to consume (MPC).

Iqbal (1985) then revised Keynes's consumption model, C = a + bYd, by incorporating zakat into the model and separating "b" into two group (zakat payers and zakat receivers), because $\mathrm{Yd}$ in Keynesian consumption model do not differentiate between these group, then the model becomes (Iqbal, 1985; Hasan, 1990; 2005):

$$
C s=a+b\left[u^{\prime} Y-\alpha u^{\prime} Y\right]+\delta\left[\left(1-u^{\prime}\right) Y+\alpha u^{\prime} Y\right] .
$$

(Model 1)

Cs is consumption, $u$ ' is percentage of muzakki (zakat payers) from population then $u^{\prime} Y$ is the share of income $(Y)$ that going to muzakki (Zakat payers). (1- $u^{\prime}$ ) is percentage of mustahik (zakat receivers) from population, thereby (1- $\left.u^{\prime}\right) Y$ is the share of income that going to mustahik (zakat receivers), $\alpha$ is certain proportion of muzakki's income that is given to mustahik because of zakat compusory, thereby, $\alpha u^{\prime} Y$ refers to amouth of zakat. - $\alpha u^{\prime} Y$ illustrates the amouth of zakat being paid by muzakki (u'Y), whereas + $\alpha u^{\prime} Y$ refers to amouth of zakat being received by mustahik [ (1-u')Y ]. b refers to muzakki's MPC whereas $\delta$ is the mustahik's MPC.

In addition, in Islamic perspective, being extravagant in consumption (israf) is prohibited, Fahim Khan in Iqbal (1985) noted that the Keynesian consumption model is not incorporating that condition, therefore lqbal (1985) modified model 1 by incorporating 
existing of israf in the analysis of Islamic consumption model. The model become as follows (model 2),

$$
C_{s}=a+\left((f) b\left[u^{\prime} Y-\alpha u^{\prime} Y\right]+b\left[u^{\prime} Y-\alpha u^{\prime} Y\right]\right)+\delta\left[\left(1-u^{\prime}\right) Y+\alpha u^{\prime} Y\right]
$$

Model 2 is level of consumption by incorporating the existence of israf and zakat. In addition, Hasan (1990) argued that level of israf is more than 0 to 0,25 , or $0<f \leq 0,25$, with $f$ is level of israf. The model is called moderation in consumption model because incorporating israf (with assumption to be 0), and zakat (that is used to minimise the one of being israf)

By using model 2, and assuing that level of israf (f) is zero, then the model can explain level of MPC of muzakki and mustahik. Furthermore, after gaining MPC of both, simple calculation based on the model can be used to generate expected moderate level of consumption, still, by assuming $f=0$ and see what happened when regressing the generated one to inflation. The term "moderate consumption" is because the model incorporates zakat and also israf (with assumption of zero level of israf) (Choudhury, M.A and Malik (1992); Abdul-Rahman (2010)). Furthermore, model 2 can bring further analysis if level of israf being activated by assuing $0<\mathrm{f} \leq 0,25$, and see what happen to the level of consumption in the existence of israf on inflation

\subsection{Inflation}

Inflation is a general and ongoing rise in the level of price in an entire economy (OpenStax, 2014), but not refer to relative price since relative price is the price of goods relative to other goods (Mankiw, 2012). In Indonesia, statistics Indonesia measures inflation using CPI (Consumer Price Index) that is calculated by modified laspeyres formula. Bank of Indonesia Metadata publication for measuring inflation (March 2016) defines CPI as a measurement of the average change over time in the price paid by consumers for a market basket of consumer goods and services.

\subsection{Zakat}

Referring Islahi (1992), there are many redistributive scheme provided by Islam, one of it is zakat. Islahi (1992) also explained that zakat should be collected from the rich and reimbursed to the poor where that activity is the essence of redistribution. Retsikas (2014)defines zakat as the 'obligatory payment by Muslims of a determinate portion of 
their lawful property for the benefit of the poor and other enumerated classes'. Mannan (1995) argued that one benefit of zakat encourage people to invest their idle properties.

\section{Research Method}

Model 2, firstly, is used to generate MPC of muzakki and mustahik by assuming level of israf (f) being zero, and then the model can be used to generate expected moderate consumption (consumption that has incorporates zero level of israf and zakat) and regressed it on inflation to see the effect. Model 2 also can be used to analyse of existing israf eventhough zakat has been paid by muzakki. The generated level of consumption from the model with existing level of israf $(0<f \leq 0,25)$ then will be regressed to inflation to see the effect.

The main problem of model 2 is how to gain data of muzakki percentage from population ( $\left.u^{\prime}\right)$ and mustahik percentage (1- $\left.u^{\prime}\right)$ from population since that kind of data is rare in Indonesia especially in time series form. To deal with the problem, this research use analysis of venn diagram to gain muzakki percentage from population (u') first. Generally speaking, the main characteristics of muzakki is the one who is not categorized as the poor and Muslim. By just these two characteristics, venn diagram (To know the simple example about venn diagram, see, Bennett, Albert B. And Nelson, L. Ted. 2004. Mathematics for Elementary Teachers: A Conceptual Approach (6th. Ed). New York: McGraw-Hill Pp. 67-69) can be utilised for generating muzakki percentage from population. The following steps present the way to generate percentage of muzakki from population (see appendix $\mathbf{1}$ for application of the steps).

1. Find total population data (imagine as letter " $g$ "), and percentage level of poverty (imagine as letter "h"), then percentage of non-poor can be gained by (1-h).

2. Total of non-poor population (imagine as letter "i") can be gained by $\mathrm{g} \times(1-\mathrm{h})$.

3. Gaining fix level of percentage muslim population (imagine as letter "j"), total muslim population (imagine as letter "M") can be generated by $\mathrm{j} \times \mathrm{g}$

4. The next step, total muzakki (imagine as letter "Tu"') can be generated by (M+i)$\mathrm{g}$, which based on venn diagram calculation principle. Then, making that "Tu"' becomes percentage form, (u'), by Tu'/g. By doing the step, muzakki percentage from population can be gained.

5. For generating mustahik percentage from population, just doing simple math as (1- u'). 
The generated " $u$ "' value can delineate the rough percentage of muzakki from population that can be used to analyse model 2 empirically.

To study modified keynesian model in model 2 , or moderate level of consumption model empirically, this research uses only 15 time series data (from 2002 - 2016) in all variables because of the very lack of data on zakat. The first step after gaining level of "u"' is to gain MPC of muzakki and mustahik and also to generate level of consumption (expected moderate consumption) from the model 2 by assuming that muzakki is not doing israf behavior $(\mathrm{f}=0$ ). Therefore, simple regression is employed to gain these MPC and to see whether the parameters is Best Linear Unbiased Estimator (BLUE), some diagnostic tests will be employed such as serial correlation test, heteroscedasticity test, normality test, functional form test. Then as the data is time series, to avoid spurious regression (nonsense regression), unit root test with ADF will be employed on the residual estimated.

Furthermore, as the other objective of model 2 is to see the effect of israf in the modified keynesian consumption model on inflation eventhough zakat has been paid by muzakki, the generated level of consumption (expected consumption with level of Israf) will be regressed to inflation based on different level of israf (from 0,05 to 0,5 ) to see the effect. for making sure that sensitivity value is valid, or BLUE, several diagnostic tests will be employed and also unit root test in the residual data.

\section{Result}

\subsection{Empirical study of modified Keynesian consumption model}

The first step to study moderate consumption model (model 2 ) empirically is to gain percentage of muzakki from population ( $\left.u^{\prime}\right)$ by using analysis of venn diagram. After employing step by step to gain percentage of muzakki (see the steps in application in appendix 1), time series value of u' (percentage of muzakki from population) will be gained, and from that value, the value of 1- $u^{\prime}$ (percentage of mustahik from population) can also be generated (see appendix $\mathbf{2}$ for descriptive statistics of muzakki and mustahik).

As percentage of muzakki and mustahik have been generated, variables income that going to mustahik [ $u^{\prime} Y+\alpha u^{\prime} Y$ ], and income that going to muzakki [ $u^{\prime} Y-\alpha u^{\prime} Y$ ] is gained, then simple regression is employed with annual data of consumption that is gained from worldbank to see MPC of muzakki and mustahik. The regression result is presented in this table. 
TABLE 1: Operational Definition.

\begin{tabular}{|c|c|c|c|}
\hline Variable & Definition & Proxy & Source of Data \\
\hline Inflation (Y) & $\begin{array}{l}\text { a general and ongoing } \\
\text { rise in the level of } \\
\text { price in an entire } \\
\text { economy }\end{array}$ & CPI & $\begin{array}{l}\text { Annual CPI from } \\
\text { worldbank (15 years). }\end{array}$ \\
\hline \multirow[t]{8}{*}{ Islamic Consumption } & $\begin{array}{l}\text { Consumption that } \\
\text { discourage } \\
\text { extravagant } \\
\text { consumption (israf) } \\
\text { and incorporating } \\
\text { zakat }\end{array}$ & $\begin{array}{l}\text { Variables needed in } \\
\text { model } 1 \text { and } 2 \text {, }\end{array}$ & $\begin{array}{l}\text { 1. population growth : } \\
\text { World Bank (annual } \\
\text { rate) }\end{array}$ \\
\hline & & 1. Total Population & $\begin{array}{l}\text { 2. Poverty headcount } \\
\text { ratio: World Bank ( } 15 \\
\text { years) }\end{array}$ \\
\hline & & $\begin{array}{l}\text { 2. percentage under } \\
\text { poverty line }\end{array}$ & $\begin{array}{l}\text { 3. Muslim Population : } \\
\text { CIA }\end{array}$ \\
\hline & & $\begin{array}{l}\text { 3. percentage of } \\
\text { muslim population }\end{array}$ & $\begin{array}{l}\text { 4. Total Zakat : } \\
\text { BAZNAS (15 years) }\end{array}$ \\
\hline & & 4. Total Zakat & $\begin{array}{l}\text { 5. GDP : World bank } \\
\text { (15 Years) }\end{array}$ \\
\hline & & 5. Income (GDP) & $\begin{array}{l}\text { 6. Household final } \\
\text { consumption } \\
\text { expenditure per } \\
\text { capita: World bank (15 } \\
\text { years) }\end{array}$ \\
\hline & & 6. consumption & $\begin{array}{l}\text { 7. Official exchange } \\
\text { rate : World bank ( } 15 \\
\text { years) }\end{array}$ \\
\hline & & 7. exchange rate & \\
\hline
\end{tabular}

TABLE 2: Regression result, with dependent variable is consumption.

\begin{tabular}{l|l|l|l|l}
\hline Variable & Coefficient & Std. Error & t-statistic & Prob. \\
\hline C & $2.90 \mathrm{E}+11$ & $5.91 \mathrm{E}+09$ & 49,13 & 0,000 \\
\hline [u'Y - $\left.\alpha \mathrm{u}^{\prime} \mathrm{Y}\right]$ (Muzakki) & $2.94 \mathrm{E}-05$ & $1.22 \mathrm{E}-06$ & 24,11 & 0,000 \\
\hline [u'Y $\left.+\alpha \mathrm{u}^{\prime} \mathrm{Y}\right]$ (Mustahik) & $3.09 \mathrm{E}-05$ & $6.26 \mathrm{E}-06$ & 4,94 & 0,000 \\
\hline R-Squared: 0,997 & Diagnostic tests & & \\
& Serial Correlation: & $0,362(0,705)$ & \\
& Heteroscedasticity: & $2,439(0,129)$ \\
& Normality: & $1,275(0,528)$ & \\
& Multicollinearity: & 5,94 & $0,421(0,53)$ \\
& functional Form: & $-3,465(0,026)$ & \\
& Residual unit root: &
\end{tabular}

Above result shows that coefficients is BLUE as residual from the model pass several diagnostic tests as such heteroscedasticity, multicollinearity, normality, and serial correlation and functional form. 
Gujarati and Porter (2009: 762) warned that "the regression of a nonstationary time series on another nonstationary time series may produce a spurious regression. However, They then explained more that if linier combination, or residual term (u), of that nonstationary variables produce $(u)$ that stationer in level, or $I(0)$, then it can be said that the model "would be meaningful (i.e., not spurious)".

Stationarity test using ADF with maximum lag 2 for each variables are presented in appendix 3, then stationarity for residual is presented in appendix 4. By using ADF test for unit root, null hypothesis that stated "residual has a unit root" can be rejected with $5 \%$ level of significance. This result prove that the model is free from spurious regression as residual is integrated in order $0,1(0)$. Result of the model also confirm what lqbal (1985), Siddiqi (1996), and Olanipekun, Brimah, \& Sanusi (2015) explained that muzakki has less MPC compared to mustahik after paying zakat. The regression result can be interpreted that the higher amount of zakat which is given from muzakki to mustahiq, will be followed by the higher aggregate consumption.

\subsection{Empirical study of moderate consumption on inflation}

The next steps is to see the effect of expected moderate consumption to inflation. Expected moderate level of consumption (Cs) can be gained from model 2 with assumption that there is no extravagant consumption (israf) or $\mathrm{f}=0$. after MPC of muzakki and mustahik are known from the previous regression, recalculating "Cs" in model 2 will generate expected level of moderate consumption that will be regressed to inflation to see the effect. Table below summarised the result of regression of expected moderate level of consumption to Inflation.

TABLE 3: regression result.

\begin{tabular}{|c|c|c|c|c|}
\hline \multicolumn{5}{|l|}{ Dependent variable: log inf } \\
\hline Regressor & Coefficient & $\begin{array}{l}\text { Standard } \\
\text { Error }\end{array}$ & T-Statistics & P-value \\
\hline Log Modcons (Moderate Consumption) & $-1,087$ & 0,367 & $-2,96$ & 0,011 \\
\hline C (Constanta) & 31,131 & 9,88 & 3,15 & 0,008 \\
\hline \multicolumn{5}{|l|}{ R-squared : 0,402 } \\
\hline \multicolumn{5}{|l|}{ Diagnostic tests } \\
\hline \multicolumn{5}{|l|}{ Autocorrelation : 0,267 $(0,77)$} \\
\hline \multicolumn{5}{|l|}{ Heteroscedasticity : 1,59 $(0,23)$} \\
\hline \multicolumn{5}{|l|}{ Functional Form : 1,015 $(0,904)$} \\
\hline \multicolumn{5}{|l|}{ Normality : $1,54(0,46)$} \\
\hline Source : Researcher's own computation, & & & & \\
\hline
\end{tabular}


The above regression gives information that moderate consumtion has negative relation on inflation, meaning that higher consumption will not followed by higher level of inflation, with $95 \%$ significant level. As the moderate level of consumption is generated by incorporationg zakat that muzakki pays and received by mustahik, the result can be stated that the higher amount of zakat which is given from muzakki to mustahik will be followed by the higher level of aggregate consumption. Empirical study of expected moderate consumption from model 2 with $f=0$ to inflation gives the information that the higher amouth of zakat paid by muzakki to mustahik will not followed by the higher level of inflation as depicted in the negative sensitivity value of islamic consumption to inflation.

The result is BLUE as pass some important diagnostic tests such as Autocorrelation, heteroscedasticity, functional form, and normality test. Furthermore, this regression is not spurious as linier combination of the regression produce residual term that has stationarity in level, $\mathrm{I}(0)$. The stationarity test for each variables are presented in appendix $\mathbf{5}$ and for the result of stationarity test in residual fro the model is presented in appendix 6.

\subsubsection{Existing Israf}

Above explanation of empirical study on moderate consumption is under assuption that $f$ in model 2 is zero or muzakki does not doing israf (extravagant consumption) after paying zakat. However, what if level of israf is more than zero?. To answer this question, model 2 will be utilised with the value of israf is $0<f \leq 0,50$. The time series of above level of expected consumption with israf then is regressed with inflation. As the model in all level of $f$ do not pass heteroscedasticity only, from henceforth the model is transformed into logarithm The following tables give the result of sensitivity analysis from regression of consumption in model 2 with $f$ is is $0<f \leq 0,50$ to inflation.

TABLE 4: Sensitivity Analysis.

\begin{tabular}{l|c|}
\hline level of Israf & Sensitivity (cons $\rightarrow$ Inf) \\
\hline 0,05 & $-1,05$ \\
0,1 & $-1,03$ \\
0,15 & $-1,01$ \\
0,2 & $-0,98$ \\
0,25 & $-0,96$ \\
0,5 & $-0,88$ \\
\hline Source: Researcher's own computation, 2018
\end{tabular}


In sensitivity analysis where level of israf is assumed to be more than zero, this means that after muzakki paying zakat they still consume that is categorised as extravagant consumption. The result shows as level of israf increase, sensitivity relation between consumption and inflation become weakened. Take some example from table 4, if level of israf is $5 \%$, consumption that is generated by zakat will reduce level of inflation for about $1,05 \%$, meaning that zakat will stabilise level of inflation through consumption is about 1,05\%. But without israf, zakat will reduce level of inflation for about 1,087\% (see table 3).

Furthermore, if level of israf is assumed to be $25 \%$, consumption that is generated by zakat will reduce level of inflation to $0,96 \%$, meaning that zakat will stabilise level of inflation through consumption is about $0,96 \%$. Based on this analysis, it can be said that the existence of israf will gradually grind sensitivity of zakat to stabilise inflation. Israf will grind sensitivity of zakat because as people consume more luxury goods that is categorised as elastic, the price become higher, making inflation to rise. This is on how israf reduce zakat capability to stabilise inflation.CONCLUSION

The main objective of this paper is to investigate on how to control level of inflation through modified keynesian consumption model. The Keynesian consumption model then is modified by incorporationg zakat, and israf. The result shows that zakat will affect consumption of muzakki and mustahik with MPC of muzakki is less than mustahik. Then, expected moderate consumption affects inflation negatively. As expected moderate level of consumption is generated from zakat, it can be said that higher zakat that is paid by muzakki will not be followed by higher level of inflation. In addition, the model also shows that as level of israf rise, the ability of zakat to stabilise inflation will grind gradually.

\section{References}

[1] Abdul-Rahman, Y. (2010). The art of Islamic finance and banking?: tools and techniques for community-based banking,. New Jersey: John Wiley\&Sons.

[2] Bank Indonesia Annual Report. (2016). Mengoptimalkan Potensi, Memperkuat Resiliensi. Annual Report 2016.

[3] Choudhury, M.A and Malik, U. . (1992). The Foundations of Is/amic Political Economy. London: The Macmillan Press.

[4] Gujarati, Damodar N. and Porter, D. C. (2009). Basic Econometrics (5th ed.). New York: McGraw-Hill Irwin. 
[5] Hasan, Z. (1990). Zakat, Moderation and Aggregate Consumption in an Islamic Economy?: Comments. JKAU: Is/amic Econ, 2, 91-100. https://doi.org/10.4197/islec. 2-1.6

[6] Hasan, Z. (2005). Treatment of Consumption in Islamic Economics: An Appraisal. JKAU: Is/amic Econ, 18(2), 29-46. https://doi.org/10.5897/JAERD12.088

[7] Iqbal, M. (1985). Zakah, Moderation and Aggregate Consumption in An Islamic Economy. J. Res. Islamic Econ, 3(1), 45-61.

[8] Islahi, A. A. (1992). Islamic Distributive Scheme: A Concise Statement. Munich Personal RePEc Archive, Paper No.(posted 6 April 2011 22:38 UTC).

[9] Johari, F., Ab. Aziz, M.R., \& Mohd Ali, A. F. (2014). A review on literatures of Zakat Between 2003-2013. Library Philosophy and Practice (e-Journal), (1175).

[10] Kenward, L. R. (2013). Inflation Targeting in Indonesia, 1999-2012: An Ex-post Review. Bulletin of Indonesian Economics Studies, 49(3), 305-327.

[11] Mankiw, N. G. (2012). Macroeconomics (8th ed.). New York: Worth Publisher.

[12] Mannan, M. A. (1995). Teori dan Praktik Ekonomi Islam. Yogyakarta: PT. Dana Bhakti Wakaf.

[13] Nishizaki, K. And Watanabe, T. (2000). Output-Inflation Trade-Off at Near-Zero Inflation Rate. Journal of the Japanese and International Economics, 14, 304-326.

[14] Olanipekun, W.D., Brimah, A.N., \& Sanusi, H. B. (2015). The Role of Zakat as Poverty Alleviation Strategy and Tool for Sustainable Development: Insight from The Perspective of the Holy Prophet (PBUH). Arabian Journal of Business and Management Review (Oman Chapter), 5(3), 8-17.

[15] Siddiqi, M. N. (1996). Role of Fiscal Policy in Controlling Inflation in Islamic Framework. Retrieved from https://www.google.co.id/search?q= Role+of+Fiscal+Policy+in+Controlling+Inflation+in+Islamic+Framework\&oq= Role+of+Fiscal+Policy+in+Controlling+Inflation+in+Islamic+Framework\&aqs= chrome..69i57.382j0j4\&sourceid=chrome\&ie=UTF-8

\section{Appendix}

\section{Appendix 1. Calculation of percentage muzakki and mustahik from population using venn diagram concept}

Appendix 1a. Generating income of muzakki and income of mustahik after (u') and (1-u') are known 


\begin{tabular}{|c|c|c|c|c|c|c|c|c|c|}
\hline Year & $\begin{array}{l}\text { total } \\
\text { population } \\
\text { (g) }\end{array}$ & $\begin{array}{l}\text { \% Poverty } \\
\text { (h) }\end{array}$ & $\begin{array}{c}\text { \% non-poor } \\
\text { (1-h) }\end{array}$ & $\begin{array}{c}\text { total } \\
\text { non-poor (i) }= \\
g \times(1-h)\end{array}$ & $\begin{array}{c}\% \text { muslim } \\
\text { population } \\
(\mathbf{j})=87,2 \%\end{array}$ & $\begin{array}{l}\text { total muslim } \\
\text { population (M) } \\
\quad=\mathbf{j} \times \mathbf{g}\end{array}$ & $\begin{array}{l}\text { Total muzakki } \\
(\text { Tu') }=(M+i)-g\end{array}$ & $\begin{array}{c}\% \text { muzakki } \\
\text { from } \\
\text { population } \\
\left(u^{\prime}\right)=T u^{\prime} / g\end{array}$ & $\begin{array}{c}\% \text { of } \\
\text { Mustahiq } \\
\text { (1-u') }\end{array}$ \\
\hline 2002 & 217508059 & 0,23 & 0,77 & 167481205,4 & 0,872 & 189667027,4 & 139640173,9 & 0,642 & 0,358 \\
\hline 2003 & 220545214 & 0,226 & 0,774 & 170701995,6 & 0,872 & 192315426,6 & 142472208,2 & 0,646 & 0,354 \\
\hline 2004 & 223614649 & 0,239 & 0,761 & 170170747,9 & 0,872 & 194991973,9 & 141548072,8 & 0,633 & 0,367 \\
\hline 2005 & 226712730 & 0,211 & 0,789 & 178876344 & 0,872 & 197693500,6 & 149857114,5 & 0,661 & 0,339 \\
\hline 2006 & 229838202 & 0,274 & 0,726 & 166862534,7 & 0,872 & 200418912,1 & 137443244,8 & 0,598 & 0,402 \\
\hline 2007 & 232989141 & 0,225 & 0,775 & 180566584,3 & 0,872 & 203166531 & 150743974,2 & 0,647 & 0,353 \\
\hline 2008 & 236159276 & 0,214 & 0,786 & 185621190,9 & 0,872 & 205930888,7 & 155392803,6 & 0,658 & 0,342 \\
\hline 2009 & 239340478 & 0,182 & 0,818 & 195780511 & 0,872 & 208704896,8 & 165144929,8 & 0,69 & 0,31 \\
\hline 2010 & 242524123 & 0,157 & 0,843 & 204447835,7 & 0,872 & 211481035,3 & 173404747,9 & 0,715 & 0,285 \\
\hline 2011 & 245707511 & 0,133 & 0,867 & 213028412 & 0,872 & 214256949,6 & 181577850,6 & 0,739 & 0,261 \\
\hline 2012 & 248883232 & 0,117 & 0,883 & 219763893,9 & 0,872 & 217026178,3 & 187906840,2 & 0,755 & 0,245 \\
\hline 2013 & 252032263 & 0,094 & 0,906 & 228341230,3 & 0,872 & 219772133,3 & 196081100,6 & 0,778 & 0,222 \\
\hline 2014 & 255131116 & 0,079 & 0,921 & 234975757,8 & 0,872 & 222474333,2 & 202318975 & 0,793 & 0,207 \\
\hline 2015 & 258162113 & 0,072 & 0,928 & 239574440,9 & 0,872 & 225117362,5 & 206529690,4 & 0,8 & 0,2 \\
\hline 2016 & 261115456 & 0,065 & 0,935 & 244142951,4 & 0,872 & 227692677,6 & 210720173 & 0,807 & 0,193 \\
\hline
\end{tabular}

\begin{tabular}{|c|c|c|c|c|c|c|c|c|c|}
\hline Tahun & $\begin{array}{c}\text { Total } \\
\text { aggregate } \\
\text { Consumption }\end{array}$ & $\begin{array}{c}\text { u' } \\
\text { (Muzakki) }\end{array}$ & $Y(G D P)$ & $u^{\prime} x Y(G D P)$ & $\alpha \mathbf{u}^{\prime} Y$ (Zakat) & {$\left[u^{\prime} Y-\alpha u^{\prime} Y\right]=Y$ muzakki } & $\begin{array}{c}\text { (1-u) } \\
\text { mustahiq }\end{array}$ & $\begin{array}{c}\left(1-u^{\prime}\right) \times Y \\
(G D P)\end{array}$ & $\begin{array}{c}{\left[\left(1-u^{\prime}\right) \mathbf{Y}+\alpha \mathbf{u}^{\prime} \mathbf{Y}\right]=\mathbf{Y}} \\
\text { mustahik }\end{array}$ \\
\hline 2002 & $3,36943 E+11$ & 0,642 & $1,93971 E+15$ & $1,24529 E+15$ & 324997852 & 1245291633715750,00 & 0,36 & $6,94415 E+14$ & 694415467084252,00 \\
\hline 003 & $3,52405 E+11$ & 0,646 & $2,14394 E+15$ & $1,38498 E+15$ & 971406813 & 1384983890553990,00 & 0,35 & $7,58955 E+14$ & 758955524246012,00 \\
\hline 004 & $3,69499 E+11$ & 0,633 & $2,44442 E+15$ & $1,54732 E+15$ & 1514433499 & 1547315029559500,00 & 0,37 & $8,97101 \mathrm{E}+14$ & 897102891440499,00 \\
\hline 2005 & $3,85279 E+11$ & 0,661 & $2,95383 E+15$ & $1,95248 \mathrm{E}+15$ & 1808018400 & 1952480954803400,00 & 0,34 & $1,00135 E+15$ & 1001350758996600,00 \\
\hline 2006 & $4,00504 \mathrm{E}+11$ & 0,598 & $3,55528 \mathrm{E}+15$ & $2,12606 \mathrm{E}+15$ & 3146559708 & 2126052959661090,00 & 0,40 & $1,42922 \mathrm{E}+15$ & 1429224809938910,00 \\
\hline 2007 & 4,19988E+11 & 0,647 & $4,2066 \mathrm{E}+15$ & $2,72167 E+15$ & 4280119174 & 2721663843010830,00 & 0,35 & $1,48493 E+15$ & 1484932946989170,00 \\
\hline 008 & $4,45102 E+11$ & 0,658 & $5,26896 \mathrm{E}+15$ & $3,46698 E+15$ & 10999194974 & 3466964693965030,00 & 0,34 & $1,80198 \mathrm{E}+15$ & 1801995326034970,00 \\
\hline 2009 & $4,73067 E+11$ & 0,69 & $5,96901 E+15$ & $4,11862 E+15$ & 13726055726 & 41186064755994270,00 & 0,31 & $1,85039 E+15$ & 1850408309405730,00 \\
\hline 010 & $4,92496 E+11$ & 0,715 & $7,0459 E+15$ & $5,03782 E+15$ & 12769270318 & 5037806723650180,00 & 0,29 & $2,00808 E+15$ & 2008094665049820,00 \\
\hline 2011 & $5,17728 E+11$ & 0,739 & $7,83879 E+15$ & $5,79286 E+15$ & 14100177242 & 5792849384041960,00 & 0,26 & $2,04592 E+15$ & 2045937468758040,00 \\
\hline 0012 & $5,45576 E+11$ & 0,755 & $8,6157 E+15$ & $6,50485 E+15$ & 18469069461 & 6504832689977540,00 & 0,25 & $2,11085 E+15$ & 2110864209422460,00 \\
\hline 2013 & $5,76413 E+11$ & 0,778 & $9,54609 E+15$ & $7,42686 E+15$ & 24142238180 & 7426834441656220,00 & 0,22 & $2,11923 E+15$ & 2119256283143780,00 \\
\hline 14 & $6,03571 E+11$ & 0,793 & $1,05696 E+16$ & $8,38173 E+15$ & 29782741431 & 8381700859297870,00 & 0,21 & $2,18792 E+15$ & 2187946860802130,00 \\
\hline 015 & $6,33208 E+11$ & 0,8 & 1,15316E+16 & $9,2253 E+15$ & 45289351355 & 9225258200648650,00 & 0,20 & $2,30633 E+15$ & 2306371161851350,00 \\
\hline$x$ & $6,6071 \mathrm{E}+11$ & 0,807 & $1,24067 E+16$ & $1,00122 E+16$ & 75199989458 & 10012116625250500,00 & 0,19 & $2,39449 E+15$ & 2394564694749460,00 \\
\hline
\end{tabular}

Appendix 2. Descriptive statistics of Muzakki and Mustahik

Appendix 3. Unit Root Test of consumption; income of muzakki [u'Y - $\left.\alpha \mathbf{u}^{\prime} \mathbf{Y}\right]$ and income of mustahik [u'Y $\left.+\alpha \mathbf{u}^{\prime} \mathbf{Y}\right]$ 


\begin{tabular}{l|c|c|} 
& Muzakki (u', \%) & Mustahik (1-u, \%) \\
\hline Mean & 0,70 & 0,29 \\
\hline Standard Error & 0,02 & 0,02 \\
\hline Median & 0,69 & 0,31 \\
\hline Standard Deviation & 0,07 & 0,07 \\
\hline Kurtosis & $-1,47$ & $-1,47$ \\
\hline Skewness & 0,22 & $-0,22$ \\
\hline Range & 0,21 & 0,21 \\
\hline Minimum & 0,59 & 0,19 \\
\hline Maximum & 0,81 & 0,40 \\
\hline Sum & 10,56 & 4,44 \\
\hline Count & 15 & 15 \\
\hline Source: Researcher's own computation, 2018 (Using MS Excel 2013)
\end{tabular}

\begin{tabular}{l|l|}
\hline Variable & Model \\
& \\
\hline Consumption & Intercept \\
& Intercept and Trend \\
& none \\
& Intercept \\
\hline Income of Muzakki & Intercept and Trend \\
& none \\
\hline Income of Mustahik & Intercept \\
\hline Intercept and Trend \\
none
\end{tabular}

\begin{tabular}{|c|c|c|}
\hline \multicolumn{2}{|c|}{$\begin{array}{l}\text { Augmented Dickey-Fuller } \\
\text { (ADF) test - t stat. }\end{array}$} & \multirow[t]{2}{*}{ Decision } \\
\hline $\begin{array}{c}\text { First } \\
\text { Difference }\end{array}$ & $\begin{array}{c}\text { Second } \\
\text { Difference }\end{array}$ & \\
\hline$-1,547$ & $-4,356^{* * *}$ & I(2) \\
\hline$-2,851$ & $-4,777^{* *}$ & I(2) \\
\hline 0,439 & $-4.024^{* * *}$ & $\mathrm{I}(2)$ \\
\hline$-1,853$ & $-5,049^{* * *}$ & I(2) \\
\hline$-2,299$ & $-4,060^{* *}$ & $\mathrm{I}(2)$ \\
\hline 0,118 & $-4,862^{* * *}$ & I(2) \\
\hline$-3,673^{* *}$ & $-10,271^{* * *}$ & $\mathrm{I}(1)$ \\
\hline$-0,538$ & $-4,402^{* *}$ & $1(2)$ \\
\hline$-0,650$ & $-4,876^{* * *}$ & $\mathrm{I}(2)$ \\
\hline
\end{tabular}

$\left({ }^{* * *}\right),\left({ }^{* *}\right),\left({ }^{*}\right)$, indicate $1 \%, 5 \%$, and $10 \%$ level of significance, respectively Source: Researcher's own computation, 2018 (Using Eviews 9)

\section{Appendix 4. Unit Root Test for residual of model 2 with assumption $f=0$}

\begin{tabular}{l|l} 
Variable & Model \\
& \\
$\begin{array}{ll}\text { Residual variable of model } \\
2(\text { with } \mathrm{f}=0)\end{array}$ & $\begin{array}{l}\text { Intercept } \\
\text { Intercept and Trend } \\
\end{array}$ \\
& none
\end{tabular}

\begin{tabular}{|c|c|}
\hline \multicolumn{2}{|c|}{$\begin{array}{l}\text { Augmented Dickey-Fuller } \\
\text { (ADF) test - t stat. }\end{array}$} \\
\hline Level & Decision \\
\hline$-3,465^{* *}$ & $\mathrm{I}(0)$ \\
\hline$-3,444^{*}$ & $\mathrm{I}(0)$ \\
\hline$-3,557^{* * *}$ & $\mathrm{I}(0)$ \\
\hline
\end{tabular}

$\left({ }^{* *}\right),\left({ }^{* *}\right),\left({ }^{*}\right)$, indicate $1 \%, 5 \%$, and $10 \%$ level of significance, respectively

Source: Researcher's own computation, 2018 (Using Eviews 9) 


\section{Appendix 5. Unit Root Test of modetar consumption and inflation}
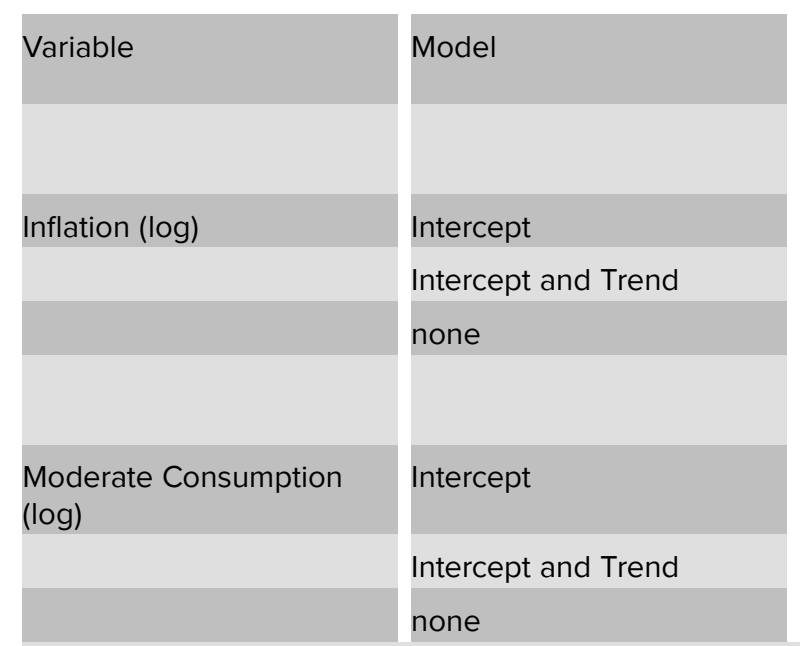

\begin{tabular}{|c|c|}
\hline \multicolumn{2}{|c|}{$\begin{array}{l}\text { Augmented Dickey-Fuller } \\
\text { (ADF) test - t stat. }\end{array}$} \\
\hline Level & $\begin{array}{c}\text { First } \\
\text { Difference }\end{array}$ \\
\hline$-2,563$ & $-5,049^{* * *}$ \\
\hline$-3,429^{*}$ & $-4,728^{* *}$ \\
\hline$-1,148$ & $-5,150^{* * *}$ \\
\hline $\begin{array}{c}\text { First } \\
\text { DIfference }\end{array}$ & $\begin{array}{l}\text { Second } \\
\text { Difference }\end{array}$ \\
\hline$-3,110^{*}$ & $-5,877^{* * *}$ \\
\hline$-2,593$ & $-7,343^{* * *}$ \\
\hline 0,141 & $-6,103^{* * *}$ \\
\hline
\end{tabular}

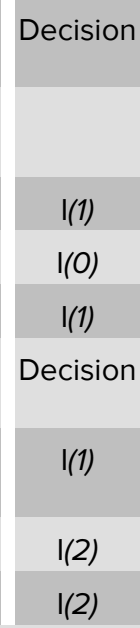

$\left.{ }^{(* *}\right),\left(^{* *}\right),\left({ }^{*}\right)$, indicate $1 \%, 5 \%$, and $10 \%$ level of significance, respectively Source: Researcher's own computation, 2018 (Using Eviews 9)

\section{Appendix 6. Unit Root Test for residual term from regression of moderate consumption to inflation}
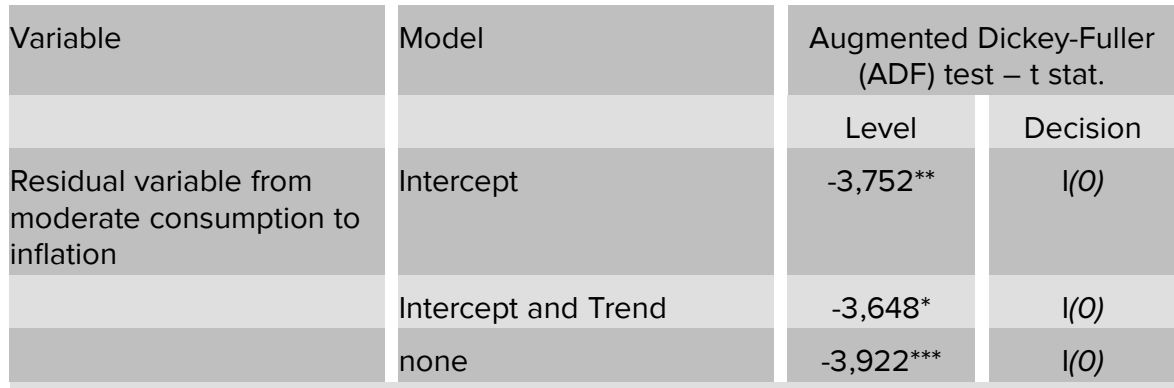

$\left({ }^{* *}\right),\left({ }^{* *}\right),\left({ }^{*}\right)$, indicate $1 \%, 5 \%$, and $10 \%$ level of significance, respectively

Source: Researcher's own computation, 2018 (Using Eviews 9)

Appendix 7. Sensitivity analysis of model 2 , with $f$ is $0<f<0,50$ 


\begin{tabular}{|c|c|c|c|c|c|}
\hline \multicolumn{3}{|l|}{ Israf $=0$} & \multicolumn{3}{|l|}{ Israf $=0,20$} \\
\hline ConsFOOO $\rightarrow$ Inf & St. Error & Prob & ConsF020 $\rightarrow$ Inf & St. Error & Prob \\
\hline$-1,08$ & 0,37 & 0,011 & $-0,98$ & 0,33 & 0,011 \\
\hline R-squared: 0,402 & & & R-squared 0,403 & & \\
\hline DW-Stat: 2,04 & & & DW-Stat: 2,05 & & \\
\hline Diagnostic tests & & & Diagnostic tests & & \\
\hline Autocorrelation & \multicolumn{2}{|c|}{$0,267(0,77)$} & Autocorrelation & \multicolumn{2}{|l|}{$0,27(0,76)$} \\
\hline Heteroscedasticity & \multicolumn{2}{|c|}{$1,586(0,23)$} & Heteroscedasticity & \multicolumn{2}{|l|}{$1,62(0,198)$} \\
\hline Functional form & \multicolumn{2}{|c|}{ 1,015 (0,904) } & Functional form & \multicolumn{2}{|c|}{$0,020(0,89)$} \\
\hline Normality & \multicolumn{2}{|l|}{$1,54(0,46)$} & Normality & \multicolumn{2}{|l|}{$1,56(0,46)$} \\
\hline \multicolumn{3}{|l|}{ Israf = 0,05 } & Israf $=0,25$ & & \\
\hline ConsF005 $\rightarrow$ Inf & St. Error & Prob & ConsF025 $\rightarrow$ Inf & St. Error & Prob \\
\hline$-1,059$ & 0,358 & 0,011 & $-0,96$ & 0,33 & 0,011 \\
\hline R-squared 0,403 & & & R-squared 0,404 & & \\
\hline DW-Stat: 2,04 & & & DW-Stat: 2,05 & & \\
\hline Diagnostic tests & & & Diagnostic tests & & \\
\hline Autocorrelation & \multicolumn{2}{|c|}{$0,267(0,77)$} & Autocorrelation & \multicolumn{2}{|l|}{$0,27(0,77)$} \\
\hline Heteroscedasticity & \multicolumn{2}{|l|}{$1,6(0,23)$} & Heteroscedasticity & \multicolumn{2}{|l|}{$1,62(0,225)$} \\
\hline Functional form & \multicolumn{2}{|c|}{$0,016(0,899)$} & Functional form & \multicolumn{2}{|c|}{$0,022(0,88)$} \\
\hline Normality & \multicolumn{2}{|l|}{$1,54(0,46)$} & Normality & \multicolumn{2}{|l|}{$1,56(0,46)$} \\
\hline Israf $=0,10$ & & & Israf = 0,50 & & \\
\hline ConsF010 $\rightarrow$ Inf & St. Error & Prob & ConsF050 $\rightarrow \operatorname{Inf}$ & St. Error & Prob \\
\hline$-1,03$ & 0,35 & 0,011 & $-0,88$ & 0,295 & 0,011 \\
\hline R-squared 0,403 & & & R-squared 0,405 & & \\
\hline DW-Stat: 2,04 & & & DW-Stat: 2,05 & & \\
\hline Diagnostic tests & & & Diagnostic tests & & \\
\hline Autocorrelation & $0,27(0,76)$ & & Autocorrelation & $0,27(0,76)$ & \\
\hline Heteroscedasticity & $1,65(0,199)$ & & Heteroscedasticity & $1,65(0,22)$ & \\
\hline Functional form & $0,018(0,9)$ & & Functional form & $0,025(0,8 \varepsilon$ & \\
\hline Normality & $1,55(0,46)$ & & Normality & $1,57(0,46)$ & \\
\hline \multicolumn{6}{|l|}{ Israf $=0,15$} \\
\hline ConsF015 $\rightarrow$ Inf & St. Error & Prob & & & \\
\hline$-1,01$ & 0,34 & 0,011 & & & \\
\hline \multicolumn{6}{|l|}{ R-squared 0,403 } \\
\hline \multicolumn{6}{|l|}{ DW-Stat: 2,05} \\
\hline \multicolumn{6}{|l|}{ Diagnostic tests (next) } \\
\hline Autocorrelation & \multicolumn{2}{|l|}{$0,27(0,77)$} & & & \\
\hline Heteroscedasticity & \multicolumn{2}{|l|}{$1,61(0,23)$} & & & \\
\hline Functional form & \multicolumn{2}{|l|}{$0,019(0,9)$} & & & \\
\hline Normality & $1,55(0,46)$ & & & & \\
\hline
\end{tabular}

